\title{
EXPLORING THE USE OF COMPUTER-MEDIATED VIDEO COMMUNICATION IN ENGINEERING PROJECTS IN SOUTH AFRICA
}

\author{
I.P. Meyer ${ }^{1 \#}$, T.J. Bond-Barnard ${ }^{1 *}$, H. Steyn ${ }^{1} \&$ J. Jordaan ${ }^{2}$
}

\section{ARTICLE INFO}

\section{Article details}

Submitted by authors 27 Jul 2015

Accepted for publication 26 May 2016

Available online $\quad 12$ Aug 2016

Contact details

* Corresponding author

Taryn.Barnard@up.ac.za

Author affiliations

1 Department of Engineering and Technology Management University of Pretoria, South Africa

2 Department of Statistics University of Pretoria, South Africa

\# The author was enrolled for an MEng (Project Management) degree in the Department of Engineering and Technology Management, University of Pretoria

\section{DOI}

http://dx.doi.org/10.7166/27-2-1298

\section{ABSTRACT}

Globally-expanding organisations that are trying to capitalise on distributed skills are increasingly using virtual project teams to shorten product development time and increase quality. These virtual teams, which are distributed across countries, cultures, and time zones, are required to use faster and better ways of interacting. Past research has shown that virtual teams that use computer-mediated communication (CMC) instead of face-to-face communication are less cohesive because they struggle with mistrust, controlling behaviour, and communication breakdowns. This study aims to determine whether project practitioners in South Africa perceive virtual teams that use videoconferencing as suffering from the same CMC disadvantages described in past research in other environments; and if they do, what the possible causes could be. This paper reports on a survey of 106 project practitioners in South Africa. The results show that these project practitioners prefer faceto-face communication over CMC, and perceive virtual teams using videoconferencing to be less cohesive and to suffer from mistrust and communication breakdowns, but not from increased conflict and power struggles. The perceived shortcomings of videoconferencing might result from virtual teams that use this medium having less time to build interpersonal relationships.

\section{OPSOMMING}

Organisasies maak toenemend gebruik van virtuele projekspanne wat verspreid is oor lande, kulture en tydsones en verbeterde maniere van interaksie benodig. Vorige navorsing het egter getoon dat virtuele spanne wat gebruik maak van rekenaar-bemiddelde kommunikasie (CMC) i.p.v. aangesig-tot-aangesig kommunikasie minder samehorig is omdat hulle sukkel met wantroue, beherende gedrag en gebrek aan kommunikasie. Hierdie studie ondersoek of 106 Suid-Afrikaanse projekpraktisyns van spanne wat videokonferensies gebruik ook meen dat die spanne ly aan die nadele van CMC wat in ander omgewings ondersoek is. Die resultate toon dat die respondente aangesig-tot-aangesig kommunikasie bo CMC verkies. Dit toon ook dat virtuele spanne wat gebruikmaak van videokonferensies minder samehorig is en ly aan wantroue en gebrek aan kommunikasie, maar nie aan verhoogde konflik en magstryd nie.

Organisations today are experimenting with various organisational structures in order to organise and leverage their human assets [1,2]. Due to global competition, organisations try to capitalise on their distributed skills to shorten development time and increase product quality. The result is that projects are increasingly distributed and project teams are split across countries, cultures, and time zones. Teleworking, which means working away from the office for a couple of days a week at home or at another facility is becoming increasingly popular. Teleworking holds benefits for both the 
employee and the employer: workers can cut out hours of commuting, and employers can save, for example, on electricity or rent if they go completely office-less. Automattic Inc. is one such company; it has 123 employees working in 26 countries, 94 cities, and 28 U.S. states, and its offices are its employees' homes [3]. Having a remote workforce enables Automattic Inc. to tap into a wider talent pool. Virtual meetings are conducted using Skype ${ }^{T M}$ and, if necessary, team members fly across the world to meet one another face-to-face.

The geographic distribution of project teams requires project managers and team members to use faster and better ways of interaction. Computer-mediated communication (CMC), such as Voice over Internet Protocol (VolP) and video over IP is becoming increasingly popular. Skype ${ }^{\mathrm{TM}}$ reported in 2011 that 65 million people sign into it daily; 42 per cent of Skype ${ }^{T M}$ calls are video calls, and 35 per cent of all small businesses in the United States of America use Skype ${ }^{\mathrm{TM}}$ as a primary communication service [4]. With advances in technology and increased mobile bandwidth, communication methods have become more and more mobile. First-generation mobile phones (1G) had only a voice facility, whereas second-generation mobile phones $(2 \mathrm{G})$ also had fax, limited data, and messaging capability. With increased mobile bandwidth, third-generation (3G) mobile phones added multimedia facilities by allowing video, audio, and graphical applications. Fourth-generation mobile phones will push the technological envelope even further by introducing three-dimensional imaging to social media applications. Using computer-mediated communication for collaboration poses new challenges; past research has shown, for example, that virtual teams using $C M C$ are affected negatively in a number of ways when CMC is used.

\section{LITERATURE REVIEW}

\subsection{Virtual teams}

The current geographical distribution of project teams, the need to perform projects faster, and enhancements in communication technologies are encouraging the use of virtual teams instead of face-to-face teams. Andres [5] defines virtual teams as groups of individuals collaborating in the execution of a specific project while located at multiple individual sites or multiple group sites. Andres [5] also states that virtual teams have been brought about by the need for organisations to complete projects faster while using the skills of people who are distributed geographically. Virtual teams work across time and space by using modern computer-driven technologies. Ebrahim et al. [6] define virtual teams as groups of geographically-, organisationally-, and/or time-dispersed workers brought together by information technologies to accomplish one or more tasks.

\subsubsection{Virtual team challenges}

Virtual teams face and present unique challenges during project execution; and these can be counterproductive if not managed effectively. A survey conducted by RW CultureWizard in 2010 [7] among employees of multinational organisations reported the following key findings:

- $\quad$ Eighty per cent of the respondents reported that they were part of a team of people based in different locations, and 63 per cent reported that nearly half of their team members were based outside of their home country.

- $\quad$ Respondents found virtual teams to be more challenging than face-to-face teams in managing conflict (73\%), making decisions (69\%), and expressing opinions (64\%).

- $\quad$ Respondents reported that the biggest hurdles to overcome when working in a virtual team were the different time zones (81\%), languages (64\%), and technology (43\%).

- $\quad$ The greatest personal challenge faced was the inability to read non-verbal cues (94\%).

- The top five challenges faced during virtual team meetings were insufficient time to build relationships $(90 \%)$, speed of decision-making $(80 \%)$, different leadership styles $(77 \%)$, the method of decision-making (76\%), and colleagues who did not participate (75\%).

Virtual teams take up more energy and effort to manage as effectively as co-located teams. The extra effort can be ascribed to the challenges faced in terms of inadequate communication, limited relationship-building opportunities, and the added complexity of distant interaction. Table 1 lists some of the disadvantages of virtual teams as uncovered by past research. 
Table 1: Disadvantages of virtual teams

\begin{tabular}{|l|c|}
\hline \multicolumn{1}{|c|}{ Disadvantages } & Reference \\
\hline Decreases monitoring and control activities & {$[8]$} \\
\hline $\begin{array}{l}\text { Vulnerable to mistrust, communication breakdowns, conflicts, and } \\
\text { power struggles }\end{array}$ & {$[9]$} \\
\hline $\begin{array}{l}\text { Cultural and functional diversity in virtual teams leads to differences } \\
\text { in the thought processes of members }\end{array}$ & {$[10]$} \\
\hline Virtual team members require special training and encouragement & {$[11]$} \\
\hline $\begin{array}{l}\text { Everything needs to be reinforced in a more structured and formal } \\
\text { process }\end{array}$ & {$[12]$} \\
\hline $\begin{array}{l}\text { It appears that virtual teams have more difficulty in developing a } \\
\text { conceptual understanding of a problem }\end{array}$ & {$[13,14]$} \\
\hline
\end{tabular}

\subsection{Videoconferencing}

Videoconferencing is undoubtedly the CMC tool that comes closest to face-to-face communication. Videoconferencing is defined as the conduct of a videoconference (also known as a video teleconference) by a set of telecommunication technologies that allow two or more locations to communicate by simultaneous two-way video and audio transmissions [14,15]. Whittaker [16] defines videoconferencing as a combination of a linguistic speech channel and a visual channel showing images of participants. Research conducted by Dawis and Weinstein [17] on the installation of videoconferencing systems indicates that the videoconferencing industry experienced high growth during 2007 and 2008. This high growth was the result of the introduction of high definition (HD) video into the market. Although the growth of videoconferencing was negative in 2009 due to the economic downturn, it regained a 12 per cent year-on-year growth for 2010 (see Figure 1).

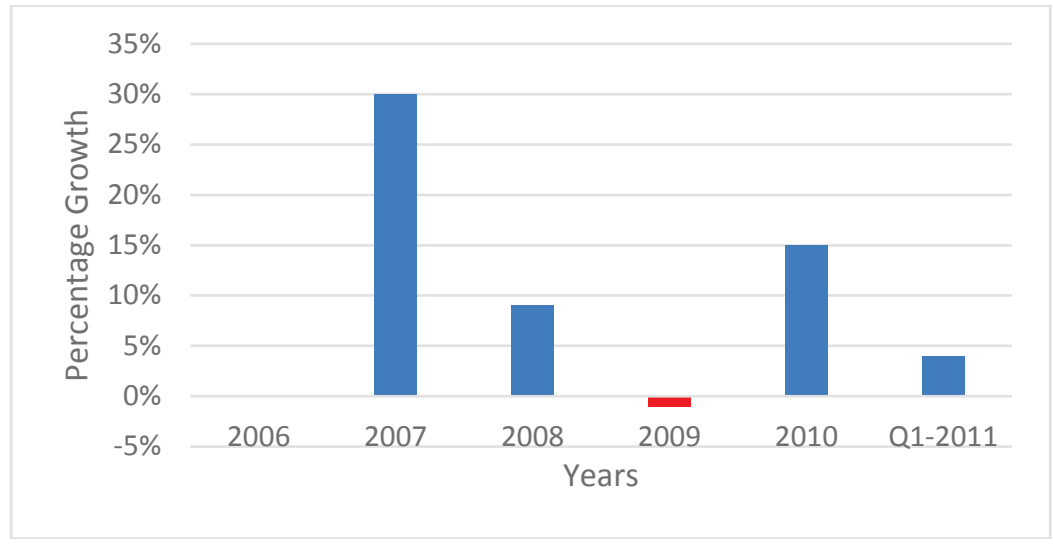

Figure 1: Videoconferencing systems - year-on-year growth $[2,18]$

A substantial amount of research has been conducted on the use of videoconferencing in distant education and in higher education learning. Greenberg [18] makes the following statement regarding the general findings about videoconferencing and higher education: "Unequivocally, two-way interactive videoconferencing technology can be an extremely effective medium for delivering quality education to a broad, geographically dispersed student population".

Videoconferencing is the only CMC medium that offers non-verbal communication cues (e.g., body language, gestures, and eye contact); this approach offers several advantages over audio- and textbased CMC. Daly-Jones et al. [19] conclude that videoconferencing enhances interpersonal awareness. Although team members do not share the same physical location during videoconferencing, they can see and hear one another (feelings, tones, gestures, etc.) and experience the immediacy of interacting [20].

\section{OBJECTIVES}

The objective of this study is to determine how South Africans working in the engineering project environment perceive virtual teams that use videoconferencing as opposed to co-located teams that use face-to-face communication. From these perceptions, this study aims also to determine whether 
virtual teams suffer from the disadvantages listed in Table 1 . In order to address the research problem effectively, the following are proposed:

Hypothesis $1 \mathbf{( H 1 ) :}$ Face-to-face communication is still the most preferred communication medium of South African engineering project practitioners, regardless of their age.

Hypothesis $2(\mathrm{H} 2)$ : When using videoconferencing (as opposed to face-to-face communication), virtual teams are more vulnerable to mistrust because the frequency of communication decreases.

Hypothesis $3(\mathrm{H} 3)$ : As opposed to face-to-face communication, virtual teams using videoconferencing are more vulnerable to communication breakdowns because the frequency of communication decreases.

Hypothesis $4(\mathrm{H} 4)$ : Virtual teams using videoconferencing experience more conflict as a result of power struggles.

Hypothesis 5 (H5): Virtual teams have more difficulty developing a conceptual understanding of a problem and, as a result, everything needs to be reinforced in a more structured/formal process.

\section{CONCEPTUAL MODEL}

The conceptual model used to investigate the criteria that project managers in South Africa and virtual team members use to form their perceptions of videoconferencing and of its disadvantages (compared with face-to-face communication) is shown in Figure 2.

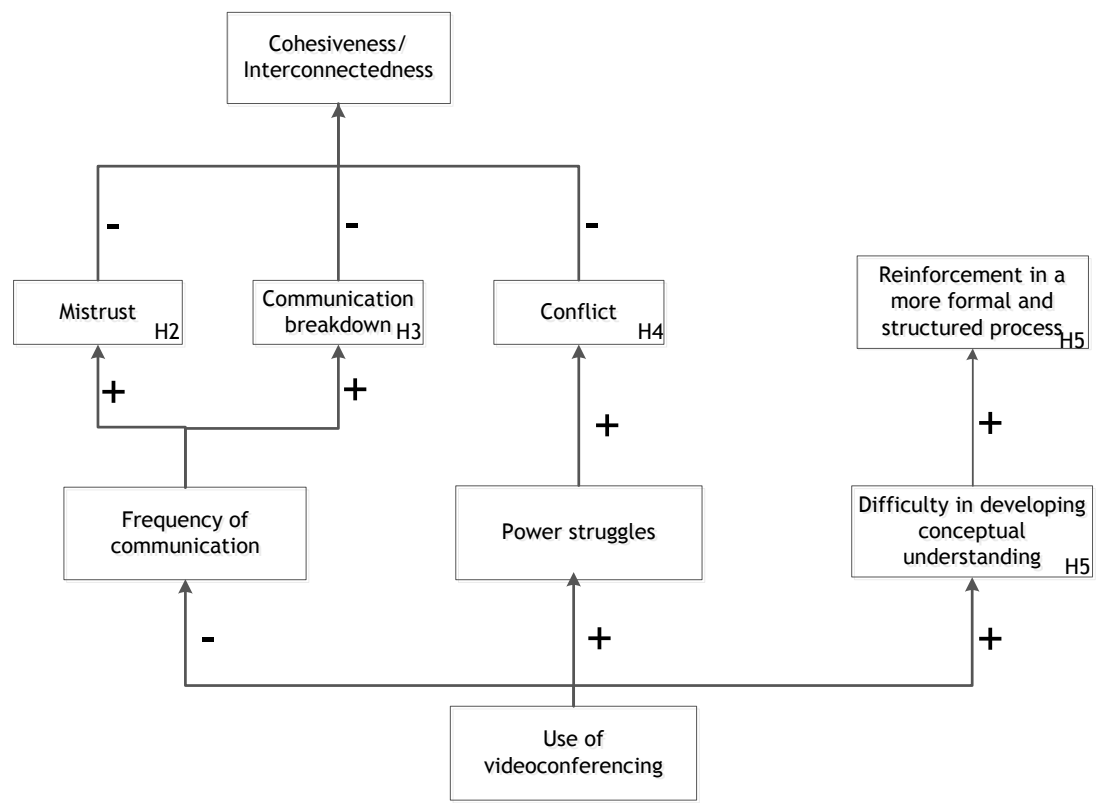

Figure 2: Conceptual model to investigate the criteria that project team members in South Africa use to form their perceptions about videoconferencing

The model suggests that using videoconferencing would cause a decrease in the frequency of communication. It is proposed that when people are not close enough to one another to be able to communicate face-to-face, the frequency of communication decreases. The decrease in communication frequency would result in an increase in both mistrust and communication breakdowns, and this would in turn result in a reduction in cohesiveness (interconnectedness/unity). Bond-Barnard et al. [21] provide a possible solution to this problem; they show that, by making use of a project call centre to facilitate and manage communication between stakeholders, the communication, collaboration, and trust improves. 
The model presented in Figure 2 proposes that a decrease in communication frequency would result in increased power struggles. An increase in power struggles would in turn result in an increase in conflict, which would lead to a reduction in cohesiveness (interconnectedness/unity).

The model also suggests that virtual teams find it more difficult to develop a conceptual understanding of a problem, and as a result everything has to be reinforced in a more structured and formal process.

\section{RESEARCH METHODOLOGY}

A questionnaire was designed to measure the respondents' perception of the criteria that influence virtual teams, based on their experience of working in and with virtual teams. Respondents were asked to rate their responses on a 5- or 3-point Likert scale about the disadvantages that are shown in the literature to influence the effectiveness of virtual teams. An excerpt from the questionnaire is shown in Appendix A.

Before undertaking the nation-wide survey, a pilot study was conducted among a five-member project reference group at General Electric Intelligent Platforms. The pilot study was conducted to validate the research intent and questions. The questionnaire was refined, based on the outcome of the pilot study.

The survey was conducted by means of an online, self-administered questionnaire distributed by email to engineering project practitioners in South Africa using snowball sampling. The unit of analysis for the study was individuals working on engineering projects in South Africa. The level of analysis was also at the individual level because it measured the individual's perception of various aspects of virtual teams. The survey ran for 23 days, and 106 valid responses were collected during that period.

\section{RESULTS}

\subsection{Reliability of the survey}

Cronbach's alpha was used as a measure of reliability. It is a measure of internal consistency that measures how closely related a set of items are as a group. Survey Questions 6 to 9 were structured on a 5-point Likert scale and Cronbach's alpha was computed for them. The questions are listed in Appendix A. The Cronbach's alpha for Questions 6 to 9 is 0.563 , suggesting that the four items have a reasonable internal consistency.

Questions 13, 14, and 16 were also structured on a 5-point Likert scale. The Cronbach's alpha for the three items is 0.384 , which suggests that the items have relatively poor internal consistency. From the results obtained, it can be concluded that the survey questions were answered fairly consistently.

The vast majority of the respondents $(93 \%)$ indicated that they use videoconferencing tools to communicate. Forty five per cent of these respondents indicated that they use videoconferencing to communicate at work. This was important to measure in order to gain an understanding of how familiar the respondents were with the subject matter.

\subsection{Testing of Hypothesis 1 (H1)}

Hypothesis 1 proposes that face-to-face communication is still the most preferred communication medium of practitioners working in the engineering project environment in South Africa, regardless of their age.

The frequency distribution of Survey Questions 5.1 to 5.7 indicates that engineering project practitioners in South Africa prefer to use face-to-face communication over email, audio-/teleconferencing, and videoconferencing. Face-to-face communication was selected by an average of 81.29 per cent of the respondents as the first choice across the various types of project communication opportunities identified by Questions 5.1 to 5.7 in Table 2. 
Table 2: Frequency distribution of Questions 5.1 to 5.7

\begin{tabular}{|c|c|c|}
\hline $\begin{array}{l}\text { Question } \\
\text { Number }\end{array}$ & Question & $\begin{array}{l}\text { Number of respondents who selected } \\
\text { an option as } 1^{\text {st }} \text { or } 2^{\text {nd }} \text { choice }\end{array}$ \\
\hline 5.1 & $\begin{array}{l}\text { Communication choices for project kick-off } \\
\text { meetings? }\end{array}$ & $\begin{array}{l}1^{\text {st }} \text { Choice: Face-to-face: } 105 \\
2^{\text {nd }} \text { choice: Video conferencing: } 74\end{array}$ \\
\hline 5.2 & $\begin{array}{l}\text { Communication choices for project progress } \\
\text { meetings? }\end{array}$ & $\begin{array}{l}1^{\text {st }} \text { Choice: Face-to-face: } 67 \\
2^{\text {nd }} \text { choice: Video conferencing: } 51\end{array}$ \\
\hline 5.3 & $\begin{array}{l}\text { Communication choices for project phase closeout } \\
\text { meetings? }\end{array}$ & $\begin{array}{l}1^{\text {st }} \text { Choice: Face-to-face: } 92 \\
2^{\text {nd }} \text { choice: Video conferencing: } 62\end{array}$ \\
\hline 5.4 & $\begin{array}{l}\text { Communication choices for discussing minor } \\
\text { disagreements with project team members? }\end{array}$ & $\begin{array}{l}1^{\text {st }} \text { Choice: Face-to-face: } 65 \\
2^{\text {nd }} \text { choice: Video conferencing: } 34\end{array}$ \\
\hline 5.5 & $\begin{array}{l}\text { Communication choices for discussing minor } \\
\text { disagreements with clients? }\end{array}$ & $\begin{array}{l}1^{\text {st }} \text { Choice: Face-to-face: } 80 \\
2^{\text {nd }} \text { choice: Video conferencing: } 46\end{array}$ \\
\hline 5.6 & $\begin{array}{l}\text { Communication choices for discussing major } \\
\text { disagreements with project team members? }\end{array}$ & $\begin{array}{l}1^{\text {st }} \text { Choice: Face-to-face: } 96 \\
2^{\text {nd }} \text { choice: Video conferencing: } 58\end{array}$ \\
\hline 5.7 & $\begin{array}{l}\text { Communication choices for discussing major } \\
\text { disagreements with clients? }\end{array}$ & $\begin{array}{l}1^{\text {st }} \text { Choice: Face-to-face: } 99 \\
2^{\text {nd }} \text { choice: Video conferencing: } 63\end{array}$ \\
\hline
\end{tabular}

\subsubsection{Cross-tabulation by age group}

In order to determine whether $\mathrm{H} 1$ is only true for certain age groups, the following sub-hypotheses are proposed:

$\mathrm{H} 1_{0}$ : There is no association between face-to-face communication and a specific age group.

$\mathrm{H} 1_{1}$ : There is a significant association between face-to-face communication and a specific age group.

In order to investigate sub-hypotheses $\mathrm{H}_{1}$ and $\mathrm{H}_{1}{ }_{1}$, Questions 5.1 to 5.7 were cross-tabulated with Question 4, which indicated the respondent's age group (see Appendix A for the questions). The Pearson chi-square test was used to test whether the null hypothesis is true at the five per cent level of significance. The Pearson chi-square test (or chi-square test for independence) is used to discover whether there is a relationship between two categorical variables [22].

The results from the cross-tabulation indicated that seven of the questions produced $p$-values below 0.05 , which indicates significance at the five per cent level. Fisher's exact test was performed on these seven cross-tables in order to verify the results. None of the significant results were related to face-to-face communication as a first choice and a particular age group. The results are summarised in Table 3.

Table 3: Cross-tabulation of Questions 5.1 - 5.7

\begin{tabular}{|l|l|}
\hline \multicolumn{1}{|c|}{ Question } & $p$-value \\
\hline Communication choice for project kick-off meetings - Video conferencing * Age groups & 0.068 \\
\hline Communication choice for project progress meetings - Video conferencing * Age groups & 0.039 \\
\hline Communication choices for project progress meetings - Video conferencing * Age groups & 0.003 \\
\hline Communication choices for discussing minor disagreements with clients - Video conferencing & 0.006 \\
\hline Communication choice for discussing major disagreements with project team members - E-mail & 0.024 \\
\hline Communication choice for discussing major disagreements with clients - E-mail & 0.007 \\
\hline Communication choice for discussing major disagreements with clients - Video conferencing & 0.015 \\
\hline
\end{tabular}

In four of the cross-tables there was a significant association between the choice of using video conferencing as a communication tool and an age group, while in two of the cross-tables there was a significant association between using e-mail as a communication tool and an age group. There was no significant association between the choice of using face-to-face as a communication tool and an age group.

Taking both the frequency distribution and the results from the cross-tabulation and Fisher's exact tests into consideration, it seems that the $\mathrm{H}_{1}$ cannot be rejected and that face-to-face communication is still the most preferred communication medium of the survey group regardless of 
their age. From the survey, however, an average of 52.1 per cent of the respondents did select videoconferencing as a second choice; this possibly indicates that videoconferencing offers some of the same advantages as face-to-face communication. It could also be that people are forced to make use of videoconferencing technologies when team members are widely distributed because it is impractical or impossible to meet face-to-face.

\subsection{Testing of Hypothesis $2(\mathrm{H} 2)$}

Hypothesis 2 proposes that when using videoconferencing (as opposed to face-to-face communication), virtual teams are more vulnerable to mistrust because the frequency of communication decreases.

The frequency distribution of Question 6 indicates that 65.1 per cent of the respondents think that virtual teams using videoconferencing are indeed more vulnerable to mistrust than are co-located teams. The frequency distribution of Questions 17 and 18 indicates that 84.9 per cent of the respondents have worked in a virtual team, and only 33 per cent of these respondents believe that the communication frequency decreases when compared with face-to-face communication.

\subsubsection{Cross-tabulation by fluctuation in frequency of communication}

In order to test whether there is an association between the use of videoconferencing and a decrease in the frequency of communication, the following sub-hypotheses are proposed:

$\mathrm{H} 2_{0}$ : There is no association between $\mathrm{Q} 6$ and Q18

$\mathrm{H}_{1}$ : There is a significant association between Q6 and Q18

To investigate sub-hypotheses $\mathrm{H} 2_{0}$ and $\mathrm{H}_{2}$, the frequencies from Question 6 were cross-tabulated with the frequencies from Question 18. The Pearson chi-square test and the Fisher's exact test were then performed to test whether the null hypothesis is true at the five per cent level of significance; these results are shown in Table 4.

Table 4: Chi-square and Fisher's exact test for Q6 and Q18

\begin{tabular}{|l|c|c|c|c|}
\hline \multicolumn{1}{|c|}{ Test } & Value & df & Asymp. Sig. (2-sided) & Exact Sig. (2-sided) \\
\hline Pearson chi-square & $22.278^{\mathrm{a}}$ & 6 & .001 & .001 \\
\hline Likelihood ratio & 25.557 & 6 & .000 & .000 \\
\hline Fisher's exact test & 21.698 & & & $<0.0001$ \\
\hline Linear-by-linear association & $3.445^{\mathrm{b}}$ & 1 & .063 & .070 \\
\hline N of valid cases & 88 & & & \\
\hline
\end{tabular}

a. Six cells (50\%) have an expected count of less than 5 . The minimum expected count is 1.48 .

b. The standardised statistic is -1.856

The chi-square test produced a $p$-value of 0.001 , which indicates that the $\mathrm{H} 2_{0}$ hypothesis can be rejected at the five per cent level of significance. This result was confirmed by the Fisher's exact test ( $p$-value less than 0.0001). From the standardised residuals given in the results, it can be concluded that virtual teams and co-located teams are equally vulnerable to mistrust when the communication frequency decreases or stays the same.

\subsection{Testing of Hypothesis $3(\mathrm{H} 3)$}

Hypothesis 3 proposes that as opposed to face-to-face communication, virtual teams using videoconferencing are more vulnerable to communication breakdowns because the frequency of communication decreases.

The frequency distribution of Question 7 indicates that 77.3 per cent of the respondents think that virtual teams using videoconferencing are indeed more vulnerable to communication breakdowns than are co-located teams. The frequency distribution of Questions 17 and 18 indicates that 84.9 per cent of the respondents have worked in a virtual team, and only 39.3 per cent of these respondents believe that the communication frequency decreases when compared with face-to-face communication.

\subsubsection{Cross-tabulation by fluctuation in frequency of communication}

In order to test whether there is an association between virtual teams using videoconferencing being more vulnerable to communication breakdowns and a decrease in the frequency of communication, the following sub-hypotheses are proposed: 
$\mathrm{H}_{3}$ : There is no association between $\mathrm{Q7}$ and Q18

$\mathrm{H}_{1}$ : There is a significant association between $\mathrm{Q} 7$ and Q18

To investigate $\mathrm{H} 3_{0}$ and $H 3_{1}$, the frequencies from Question 7 were cross-tabulated with the frequencies from Question 18. The Pearson chi-square test was then used to test the null hypothesis at the five per cent level of significance; these results are presented in Table 5.

Table 5: Chi-square and Fisher's exact test for Q7 and Q18

\begin{tabular}{|l|c|c|c|c|}
\hline \multicolumn{1}{|c|}{ Test } & Value & df & Asymp. Sig. (2-sided) & Exact Sig. (2-sided) \\
\hline Pearson chi-square & $6.485^{\mathrm{a}}$ & 6 & .371 & .379 \\
\hline Likelihood ratio & 7.596 & 6 & .269 & .350 \\
\hline Fisher's exact test & 6.551 & & & .330 \\
\hline Linear-by-linear association & $2.346^{\mathrm{b}}$ & 1 & .126 & .128 \\
\hline N of valid cases & 88 & & & \\
\hline
\end{tabular}

a. Five cells (41.7\%) have an expected count of less than 5. The minimum expected count is .89 .

b. The standardised statistic is -1.532

The chi-square test produced a $p$-value of 0.371 , which indicates that the $\mathrm{H} 3_{0}$ hypothesis cannot be rejected at the five per cent level of significance. Similarly, the Fisher's exact test produced a $p$ value of 0.330 , which is also not significant. When taking both the frequency distribution and the cross-tabulation tests into account, it seems that there is no clear indication that the frequency of communication decreases when using videoconferencing. However, the frequency distribution seems to imply that teams using videoconferencing may be vulnerable to communication breakdowns. It can thus be concluded that the communication breakdown experienced is not as a result of communication frequency decreasing.

\subsection{Testing of Hypothesis 4 (H4)}

Hypothesis 4 proposes that virtual teams using videoconferencing would experience more conflict as a result of power struggles.

The frequency distribution of Question 8 indicates that 44.3 per cent of the respondents think that virtual teams using videoconferencing are more vulnerable to conflict than are co-located teams. The frequency analysis of Question 9 indicates that 46.2 per cent of the respondents think that virtual teams using videoconferencing are more vulnerable to power struggles.

\subsubsection{Cross-tabulation between conflict and power struggles}

In order to test whether there is an association between conflict and power struggles in virtual teams using videoconferencing, the following sub-hypotheses are proposed:

$\mathrm{H} 4_{0}$ : There is no association between Q8 and Q9

$\mathrm{H} 4_{1}$ : There is a significant association between Q8 and Q9

To investigate $\mathrm{H} 4_{0}$ and $\mathrm{H} 4_{1}$, the results from Question 8 were cross-tabulated with the results from Question 9. The Pearson chi-square test was then used to test the null hypothesis at the five per cent level of significance; these results are presented in Table 6.

The chi-square test produced a $p$-value of 0.220 , which indicates that the $\mathrm{H} 4_{0}$ hypothesis cannot be rejected at the five per cent level of significance. Similarly, the Fisher's exact test produced a $p$ value of 0.232 , which is also not significant. Taking both the frequency distribution and the crosstabulation tests into account, it seems that there is no clear indication that virtual teams using videoconferencing are vulnerable to either conflict or power struggles.

\subsection{Testing of hypothesis 5 (H5)}

Hypothesis 5 proposes that virtual teams have more difficulty developing a conceptual understanding of a problem and that, as a result, everything needs to be reinforced in a more structured/formal process. 
Table 6: Chi-square and Fisher's exact test for Q8 and Q9

\begin{tabular}{|l|c|c|c|c|}
\hline \multicolumn{1}{|c|}{ Test } & Value & df & Asymp. Sig. (2-sided) & Exact Sig. (2-sided) \\
\hline Pearson chi-square & $11.880^{\mathrm{a}}$ & 9 & .220 & .221 \\
\hline Likelihood ratio & 11.065 & 9 & .271 & .347 \\
\hline Fisher's exact test & 11.116 & & & .232 \\
\hline Linear-by-linear association & $6.485^{\mathrm{b}}$ & 1 & .011 & .012 \\
\hline N of valid cases & 106 & & & \\
\hline
\end{tabular}

a. Seven cells (43.8\%) have an expected count of less than 5. The minimum expected count is .73.

b. The standardised statistic is 2.546 .

The frequency distribution of Question 10 indicates that 56.6 per cent of the respondents think that it is more difficult for virtual teams using videoconferencing to develop a conceptual understanding of a problem. The frequency distribution of Question 16 indicates that 67.9 per cent of the respondents agree that everything needs to be reinforced in a more structured/formal process in virtual teams using videoconferencing.

\subsubsection{Cross-tabulation between the conceptual understanding of a problem and structured/formal reinforcement}

In order to test whether there is an association between the questions, the following sub-hypotheses are proposed:

$\mathrm{H} 5_{0}$ : There is no association between $\mathrm{Q} 10$ and $\mathrm{Q} 16$

$\mathrm{H} 51_{1}$ : There is a significant association between $\mathrm{Q} 10$ and Q16

To investigate $\mathrm{H} 5_{0}$ and $\mathrm{H}_{1}$, the frequencies from Question 10 were cross-tabulated with the frequencies from Question 16. The Pearson chi-square test was then used to test the null hypothesis at the five per cent level of significance; these results are presented in Table 7.

Table 7: Chi-square and Fisher's exact test for Q10 and Q16

\begin{tabular}{|l|c|c|c|c|}
\hline \multicolumn{1}{|c|}{ Test } & Value & df & Asymp. Sig. (2-sided) & Exact Sig. (2-sided) \\
\hline Pearson chi-square & $11.604^{\mathrm{a}}$ & 9 & .237 & .234 \\
\hline Likelihood ratio & 13.472 & 9 & .142 & .188 \\
\hline Fisher's exact test & 11.965 & & & .156 \\
\hline Linear-by-linear association & $8.199^{\mathrm{b}}$ & 1 & .004 & .005 \\
\hline N of valid cases & 106 & & & \\
\hline
\end{tabular}

a. Nine cells (56.3\%) have an expected count of less than 5 . The minimum expected count is .42 .

b. The standardised statistic is 2.863 .

The chi-square test produced a $p$-value of 0.237 , which indicates that the $\mathrm{H} 5_{0}$ hypothesis cannot be rejected at the five per cent level of significance. Similarly, the Fisher's exact test produced a $p$ value of 0.156 , which is also not significant. Looking at the frequency distribution, it seems that virtual teams using videoconferencing might find it difficult to develop a conceptual understanding of a problem, and it also seems that conceptual understanding needs to be reinforced in a structured and formal process. However, the cross-tabulation test indicates no association between the two.

\section{CONCLUSION AND RECOMMENDATIONS}

The study confirms that, regardless of age, face-to-face communication is still the most preferred communication medium of the survey group working in engineering projects in South Africa. The study also indicates that virtual teams using videoconferencing are vulnerable to mistrust and communication breakdowns (see Figure 3), but it is not clear whether virtual teams are also vulnerable to conflict and power struggles. This might be due to the fact that members of a virtual team have less 'face time' with one another and do not get time to build relationships and connect on an interpersonal level; this results in less conflict and fewer power struggles, but more mistrust and communication breakdowns. The inability to build interpersonal relationships in virtual teams might also explain why the results indicate that virtual teams using videoconferencing are less cohesive than co-located teams using face-to-face communication. 


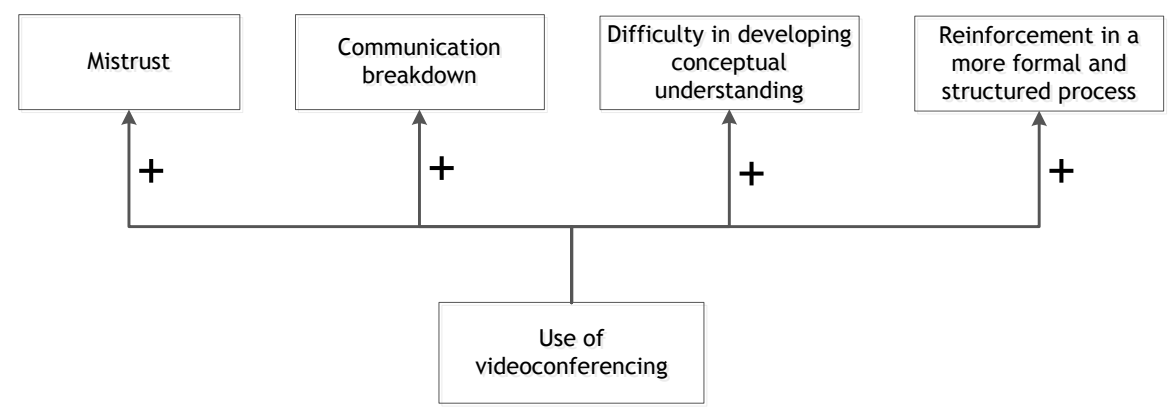

Figure 3: Model of criteria that impact project practitioners' perceptions about videoconferencing in South Africa

It appears from the results and from Figure 3 that virtual teams using videoconferencing need training and encouragement in the use of videoconferencing tools and technologies, and that conceptual understanding needs to be reinforced in a more structured and formal process. This might contribute to the fact that face-to-face communication is still the most preferred communication medium, and that videoconferencing scored only six per cent as a first-choice communication medium. Project practitioners are advised to give their project teams more training and encouragement in the use of videoconferencing technologies; this would translate into increased use of these technologies.

From the results, it is inconclusive whether the frequency of communication increases, decreases, or stays the same when using videoconferencing mediums. This might be due to the fact that the respondents might not have been exposed to the use of such technologies to the extent where they could make a meaningful prediction.

It is proposed that further research be conducted on the following areas:

How the perceptions of South African project practitioners differ from those of other countries, such as the U.S.A. and Europe, about the use of videoconferencing in projects. A case study-based analysis on the opportunities and challenges of virtual project teams in a South African and global context may further validate the findings from a practical perspective.

As a non-probability sampling technique was used to conduct the survey, the authors had little control over the sampling method; representativeness of the sample is not guaranteed; and sampling bias could have played a role, as initial subjects tend to nominate people they know well. These shortcomings should be addressed in future studies.

\section{REFERENCES}

[1] DeSanctis, G., \& Monge, P. 1999. Introduction to the special issue: Communication processes for virtual organizations. Organisational Science, 10(6), pp. 693-703.

[2] Kanawattanachai, P., \& Yoo, Y. 2002. Dynamic nature of trust in virtual teams. Sprouts Working Papers on Information Systems.

[3] McKendrick, J. 2012. How to run a 100\% virtual company. ZDNet [Online]. Available: http://www.zdnet.com/article/how-to-run-a-100-virtual-company/. [Accessed: 01-Jan-2015].

[4] Caukin, J. 2011. A Day In The Life of Skype \#Infographic. Big Blog [Online]. Available: http://blogs.skype.com/2011/09/06/a-day-in-the-life-of-skype-inf/. [Accessed: 01-Jan-2015].

[5] Andres, H. P. 2002. A comparison of face-to-face and virtual software development teams. Team Performance Management, 8(1/2), pp. 39-48.

[6] Ebrahim, N. A., Shamsuddin, A., \& Taha, Z. 2009. Virtual teams: a literature review. Australian Journal of Basic and Applied Sciences, 3(3), pp. 2653-2669.

[7] Solomon, C. 2010. The challenges of working in virtual teams. RW3 Cult Wizard. [Online]. Available: http: / /blog.rw-3.com/blog/2014/07/rw3-culturewizard-unveils-biennial-survey-results-for-effectivevirtual-teaming. [Accessed: 01-Jan-2015].

[8] Pawar, K. S., \& Sharifi, S. 1997. Physical or virtual team collocation: Does it matter? International Journal of Production Economics, 52(3), pp. 283-290.

[9] Kirkman, B. L., Rosen, B., Gibson, C. B., Tesluk, P. E., \& McPherson, S. O. 2002. Five challenges to virtual team success: Lessons from Sabre, Inc. The Academy of Management Executive, 16(3), pp. 67-79.

[10] Griffith, T. L., Sawyer, J. E., \& Neale, M. A., 2003. Virtualness and knowledge in teams: managing the love triangle of organizations, individuals, and information technology. MIS Quarterly, 27(2), pp. 265-287. 
[11] Van Ryssen, S., \& Godar, S. H. 2000. Going international without going international: multinational virtual teams. Journal of International Management, 6(1), pp. 49-60.

[12] Lurey, J. S., \& Raisinghani, M. S. 2001. An empirical study of best practices in virtual teams. Information \& Management, 38(8), pp. 523-544.

[13] Kankanhalli, A., Tan, B. C. Y., \& Wei, K.-K. 2007. Conflict and performance in global virtual teams. Journal of Management Information Systems, 23(3), pp. 237-274.

[14] Wikipedia. 2015. Videoconferencing. Wikipedia Free Encyclopaedia. [Online]. Available: https://en.wikipedia.org/wiki/Videoconferencing. [Accessed: 01-Jan-2015].

[15] Merriam-Webster Dictionary. 2015. Merriam-Webster dictionary. Merriam-Webster [Online]. Available: http://www.merriam-webster.com/. [Accessed: 01-Jan-2015].

[16] Whittaker, S. 2003. Theories and Methods in Mediated Communication. Handbook of Discourse Processes. Lawrence Erlbaum Associates, Inc.

[17] Dawis, A. W., \& Weinstein, I. M. 2011. Report: Videoconferencing by the Numbers. Wainhouse Research, LLC.

[18] Greenberg, A. D. 2009. Report: Mapping the Latest Research into Video-Based Distance Education. Wainhouse Research, LLC.

[19] Daly-Jones, O., Monk, A., \& Watts, L. 1998. Some advantages of video conferencing over high-quality audio conferencing: fluency and awareness of attentional focus. International Journal of Human Computer Studies, 49, pp. 21-58.

[20] Guo, Z., D’Ambra, J., Turner, T., \& Zhang, H. 2009. Improving the effectiveness of virtual teams: A comparison of video-conferencing and face-to-face communication in China. IEEE Transactions on Professional Communication, 52(1), pp. 1-16.

[21] Bond-Barnard, T. J., Steyn, H., \& Fabris-Rotelli, I. 2013. The impact of a call centre on communication in a programme and its projects. International Journal of Project Management, 31(7), pp. 1006-1016.

[22] Lund Research Ltd. 2013. Chi-Square Test for Association using SPSS Statistics. Laerd Statistics. [Online]. Available:

https://statistics.laerd.com/spss-tutorials/chi-square-test-for-association-using-spss-statistics.php. [Accessed: 26-May-2016]. 


\begin{tabular}{|c|c|}
\hline $\begin{array}{l}\text { Question } \\
\text { Number }\end{array}$ & Question \\
\hline 4 & What is your age? (20-29 years / 30-39 years / 40-49 years / $50+$ years) \\
\hline 5.1 & $\begin{array}{l}\text { What would be your First/Second/Third and Fourth communication choice for Project Kick-Off } \\
\text { Meetings? (Face-to-face / Email / Audio conferencing / Videoconferencing) }\end{array}$ \\
\hline 5.2 & $\begin{array}{l}\text { What would be your First/Second/Third and Fourth communication choice for Project Progress } \\
\text { Meetings? (Face-to-face / Email / Audio conferencing / Videoconferencing) }\end{array}$ \\
\hline 5.3 & $\begin{array}{l}\text { What would be your First/Second/Third and Fourth communication choice for Project Phase } \\
\text { Closeout Meetings? (Face-to-face / Email / Audio conferencing / Videoconferencing) }\end{array}$ \\
\hline 5.4 & $\begin{array}{l}\text { What would be your First/Second/Third and Fourth communication choice for Discussing minor } \\
\text { disagreements with project team members? (Face-to-face / Email / Audio conferencing / } \\
\text { Videoconferencing) }\end{array}$ \\
\hline 5.5 & $\begin{array}{l}\text { What would be your First/Second/Third and Fourth communication choice for Discussing minor } \\
\text { disagreements with clients? (Face-to-face / Email / Audio conferencing / Videoconferencing) }\end{array}$ \\
\hline 5.6 & $\begin{array}{l}\text { What would be your First/Second/Third and Fourth communication choice for Discussing major } \\
\text { disagreements with project team members? (Face-to-face / Email / Audio conferencing / } \\
\text { Videoconferencing) }\end{array}$ \\
\hline 5.7 & $\begin{array}{l}\text { What would be your First/Second/Third and Fourth communication choice for Discussing major } \\
\text { disagreements with clients? (Face-to-face / Email / Audio conferencing / Videoconferencing) }\end{array}$ \\
\hline 6 & $\begin{array}{l}\text { How vulnerable do you think virtual teams using video conferencing are to mistrust when } \\
\text { compared to co-located teams using face-to-face communication? (Much less vulnerable / Less } \\
\text { vulnerable / Same / More Vulnerable / Much more Vulnerable) }\end{array}$ \\
\hline 7 & $\begin{array}{l}\text { How vulnerable do you think virtual teams using video conferencing are to communication } \\
\text { breakdowns when compared to co-located teams using face-to-face communication? (Much less } \\
\text { vulnerable / Less vulnerable / Same / More Vulnerable / Much more Vulnerable) }\end{array}$ \\
\hline 8 & $\begin{array}{l}\text { How vulnerable do you think virtual teams using video conferencing are to conflicts when } \\
\text { compared to co-located teams using face-to-face communication? (Much less vulnerable / Less } \\
\text { vulnerable / Same / More Vulnerable / Much more Vulnerable) }\end{array}$ \\
\hline 9 & $\begin{array}{l}\text { How vulnerable do you think virtual teams using video conferencing are to power struggles when } \\
\text { compared to co-located teams using face-to-face communication? (Much less vulnerable / Less } \\
\text { vulnerable / Same / More Vulnerable / Much more Vulnerable) }\end{array}$ \\
\hline 10 & $\begin{array}{l}\text { How difficult do you think it is for virtual teams using videoconferencing to developing a } \\
\text { conceptual understanding of a problem when compared to co-located teams using face? (Much } \\
\text { less difficult / Less difficult / Same / More difficult / Much more difficult }\end{array}$ \\
\hline 13 & $\begin{array}{l}\text { Do you agree/disagree that special training should be provided to virtual teams using video } \\
\text { conferencing? (Training on the use of the technology) (Strongly disagree / Disagree / Neutral / } \\
\text { Agree / Strongly agree) }\end{array}$ \\
\hline 14 & $\begin{array}{l}\text { Do you agree/disagree that encouragement should be provided to virtual teams using video } \\
\text { conferencing? (Encouragement to make use of the technology) (Strongly disagree / Disagree / } \\
\text { Neutral / Agree / Strongly agree) }\end{array}$ \\
\hline 16 & $\begin{array}{l}\text { Everything needs to be reinforced in a more structured / formal process in virtual teams using } \\
\text { video conferencing. (Strongly disagree / Disagree / Neutral / Agree / Strongly agree) }\end{array}$ \\
\hline 17 & $\begin{array}{l}\text { Do you or have you worked on a project where electronic media had to be used to communicate } \\
\text { with team members because of the geographic distribution of team members? (Yes / No) }\end{array}$ \\
\hline 18 & $\begin{array}{l}\text { If Yes, did the frequency of communication with team members increase, stay the same, or } \\
\text { decrease when compared to co-located teams using face-to-face communication? (Decrease / } \\
\text { Same / Increase) }\end{array}$ \\
\hline
\end{tabular}

